\title{
WATER USE EFFICIENCY OF RICE AND SOYBEAN UNDER DRIP IRRIGATION WITH MULCH IN THE SOUTH-EAST OF KAZAKHSTAN
}

\author{
OSPANBAYEV, ZH. O. ${ }^{1}-$ KURMANBAYEVA, M. S. ${ }^{2 *}-$ ABDUKADIROVA, ZH. A. ${ }^{3}-$ \\ DOSZHANOVA, A. S. ${ }^{4}$ - NAZARBEKOVA, S. T. ${ }^{2}$ - INELOVA, Z. A. ${ }^{2}-$ ABLAIKHANOVA, \\ N. T. ${ }^{2}-$ KENENBAYEV, S. B. ${ }^{1}-$ MUSINA, A. S. ${ }^{3}$ \\ ${ }^{I}$ Kazakh Scientific Research Institute of Agriculture and Plant Growing \\ Almaty, Kazakhstan \\ ${ }^{2}$ Al-Farabi Kazakh National University, Almaty, Kazakhstan \\ ${ }^{3}$ Kazakh State Women's Teacher Training University, Almaty, Kazakhstan \\ ${ }^{4}$ Kazakh National Agrarian University, Almaty, Kazakhstan \\ *Corresponding author \\ e-mail: kurmanbayevakz@gmail.com \\ (Received 12 $2^{\text {th }}$ Apr 2017; accepted 12 $2^{\text {th }}$ Aug 2017)
}

\begin{abstract}
Water saving was and remains an acute problem in places with water scarcity and inaccessibility. In order to solve this problem, drip irrigation started to be used in many countries, and for the first time, in Kazakhstan, there were used cultures that consume water sufficiently in large quantities such as rice and soybean. Ways of irrigation have significant effect on elements of structure of a rice and soybean crop. Drip irrigation with a two-row tape way of crops forms essentially distinct structure of a rice crop in comparison with usual technology of cultivation of rice and soybean. Rice (Oryza sativa L.) and soybean (Glycine Max L. Merr.) crops were grown in 2013-2016 to determine effect of drip irrigation in the different variants water levels on growth and productivity under conditions of the south-east of Kazakhstan. In result of three years of researches on studying of rice and soybean drip irrigation efficiency were made the following conclusions: Drip irrigation (Di) with application of the mulching film promotes emergence of early and amicable shoots of rice and soybean, intensive growth and development of plants, productivity increase. Drip irrigation with use of the mulching film at 8-10 times reduces a contamination of crops of rice that allows to exclude application of manual use, mechanical and chemical processing of crops. Use of the mulching film under rice drip irrigation promotes creation of the favorable nitric mode of the soil with big accumulation of ammoniac and nitrate nitrogen and mobilization of motile phosphorus. The best way of rice crops under drip irrigation is 2-row tape crops with distance between tapes of $70 \mathrm{~cm}$ and a row-spacing in a tape of $30 \mathrm{~cm}$. At the same time the drip tape keeps within row-spacings in a tape. Comparison of the productivity of soybean varieties showed that productivity in variants with mulch far exceeded variants without mulching.
\end{abstract}

Keywords: Oryza sativa L., Glycine Max L. Merr., water-saving technologies, productivity

\section{Introduction}

Irrigated agriculture, the major contributor of agricultural production, faces the challenge of improving irrigation water use efficiency and meanwhile ensuring food security ( $\mathrm{Li}$ et al., 2016a). The global water consumption for irrigation has been steadily growing over the last 50 years and today it makes $70 \%$ of all water consumption (Tian et al., 2016). The great challenge of the agricultural sector is to produce more food from less water, which can be achieved by increasing Crop Water Productivity (CWP) (Zwart, 2004). Deficiency of fresh water increases in high places around the world. 
According to forecasts of FAO and IFPRI global demand for water resources according to the scenario of usual development by 2030 will increase twice. The Water Resources Committee of the Ministry of Agriculture deals with the management and allocation of water resources and water use. This situation often makes it difficult to conduct complex, integrated scientific research. State and private land ownership is recognised and equally protected. However, it is difficult to deal with the maintenance of the irrigation systems for small peasant farmers. Government support is required. Publicprivate partnership should be considered to introduce the most advanced water-saving technologies (FAO).

Especially critical situation with water supply is predicted in the countries of Central Asia because of the growing intake of water, thawing of glaciers and droughts, the processes of degradation of lands and desertification. For Kazakhstan with strong dependence on climate change and cross-border water currents, the scenario of usual development in principle does not allow to solve problems of water supply of economy and the population in the near future.

The main consumer of water resources in Kazakhstan, as well as in other countries of the Central Asian region, is the irrigation whose share is over $70 \%$ of all potential of a superficial drain. Practically in all territory of the Republic the intense water management situation is caused by a lack of water resources and pollution of water sources is present (Paramonov, 2009; Kwan et al., 2011). Annual deficiency of water in Kazakhstan makes $2-3 \mathrm{~km}^{3}$. The problem of water dependence can be dangerous to national security of Kazakhstan because of emergence of the interstate and regional conflicts (the cross-border rivers) (Water resources of Kazakhstan in the New Millennium: 2004). Alternative irrigation layouts and water management approaches could contribute to reduced water use and increased irrigation efficiency (Beecher et al., 2006).

The greatest consumer of irrigation water per unit area is rice. Rice (paddy) is the second most important commodity worldwide, and rice cropping fields significantly contribute to climate change since they are a considerable source of methane (Coltro et. al., 2016). Rice paddy agricultural methods require a large quantity of water (Kang et al., 2007). Statistics indicate that the water consumption of rice accounts for approximately $54 \%$ of the total water consumption (He et al., 2014); and more than $50 \%$ of reserves of irrigation water is spent on cultivation of this culture in Kazakhstan. In Kazakhstan, as well as in the countries of Central Asia, the way of cultivation of rice based on continuous flooding of crops is accepted. Under production conditions the irrigating norm of rice with continuous flooding and pro-accuracy changes ranging from 25 to 35 thousand $\mathrm{m}^{3} /$ hectare. Under this method of an irrigation a consumption of irrigation water on rice cultivation greatly exceeds biological need of plants for water which considerable part is lost on evaporation, filtration and feeding of ground waters. That is why rice irrigation by method of flooding is one of methods of melioration of highly salinized lands and way of fight against weeds weed control. Cultivation of rice with an expense of a huge amount of irrigation water within more than 50 years has brought to an environmental problem of Aral and in recent years of Balkhash, too. Long-term cultivation of rice with flooding of checks has led to sharp decrease in efficiency of use of the irrigated lands with considerable reduction of the areas and efficiency of other irrigated cultures. Now rice in Kazakhstan is cultivated on the area of about 100 thousand hectares. For cultivation of rice on such square about 3 billion $\mathrm{m}^{3}$ of irrigation water are annually spent. 
In this regard, undoubted relevance is acquired by the researches directed to the development of systems of agriculture and technologies providing effective use of natural and water resources, increase of efficiency of the irrigated arable land and have a strategic importance, as in national, and international scale. There is a need for an agriculture intensification, use of new breakthrough high technologies for crop cultivation. The developed nature protection technology of cultivation of rice is suitable for distribution on the irrigated lands of a zone of paddy culture in Uzbekistan, Tadzhikstan, Turkmenistan, introduction of which will provide improvements of an ecological situation in the region of the Aral-Syrdaryinsky basin and in general Central Asia.

Many water-saving technologies are currently used in rice production, including alternate wetting and drying irrigation, the rice intensification system, aerobic rice and the ground cover rice production systems (GCRPSs) (He et al., 2016). But the numerous researches, conducted mainly abroad, show that the most effective way of rational use of irrigation water is, without any doubts, the drip irrigation. Drip-irrigation is the slow and frequent application of small amounts of water (Zhu et al., 2013). Drip irrigation is the most effective way to supply water and nutrients to the plant and not only saves water but also increases yield of fruits and vegetable crops (Tiwari et. al., 2003), it also stabilizes the daily range of soil temperatures (Xing et al., 2012), which can benefit crop growth (Li et al., 2016b). Drip irrigation is a way of watering at which water is pumped in the small portions evenly to plant roots throughout all vegetative period and irrigational moisture goes only to plants, but is not spent for row-spacings. Because of it, many researchers have reported higher application efficiency of drip irrigation system over the conventional irrigation methods (Tiwari et al., 1998). Drip irrigation also has been used extensively to reclaim the salt-affected soils for crop productivity in recent years (Zhang et al., 2014). Efficiency of use of the mulching films under drip irrigation in preservation of moisture and control of weeds is proved (Raina, 1998; Seyfi, 2007). With the invention of new technologies and the equipment for drip irrigation, in foreign literature there is mentioned this method's efficiency in rice cultivation. In the separate experiments made in the USA, India, Australia, nowadays it is reported about efficiency of a combination of drip irrigation ways with zero processing of the soil or with use of the mulching films (Enciso-Medina et. al., 2001).

The use of plastic mulch in agriculture has increased dramatically in the last 10 years throughout the world (Kasirajan, 2012). Introduction mulched drip irrigation (MDI) has been widely employed in arid and semiarid regions for crop cultivation to accurately supply water and fertilizer in the soil in conjunction with soil evaporation reduction (Zhou et al., 2017). Mulched drip irrigation is a combination of the drip irrigation and the mulch technique (Liu et al., 2012). When soil temperature is insufficient, plastic mulch enhances tuber yield and water use efficiency (WUE) (Wang et al., 2011). Conventionally, mulches increase the yield and water use efficiency (WUE) to a great extent by augmenting the water status in the root zone profile (Mukherjee et al., 2010). Different types of materials like wheat straw, rice straw, plastic film, grass, wood, sand etc. are used as mulches. They moderate soil temperature and increase water infiltration during intensive rain (Yaghi et al., 2013). Drip irrigation with plastic film mulch (DI-PFM) can maintain high rice yields with significant water savings. Both plastic mulch and drip irrigation profoundly influence soil environment, especially through spatiotemporal changes in soil water (Zhang et al., 2017). However, rice seedlings often develop chlorosis when grown 
with DI-PFM on calcareous soil. Chlorosis in drip-irrigated seedlings occurs not because Fe availability is low but because the Fe uptake capacity of roots is weak at low temperatures (Zhang et. al., 2016). Rice plants are more sensitive to the $\mathrm{HCO}_{3}{ }^{-}$ concentration of irrigation water under FI than under DI-PFM (Zhang et al., 2015). Water application systems under wells extracting groundwater are one of the major factors influencing climate change in the agricultural sector. In the context of growing demand for adaption of pressurized irrigation with electric pumps in south central India, the present study was undertaken to assess the carbon dioxide emission $\left(\mathrm{CO}_{2}\right)$ for different irrigation systems. It was observed that among all the irrigation systems, the drip system gave the lowest $\mathrm{CO}_{2}$ indicating the maximum climate change mitigation potential in the irrigation sector of selected region under wells (Reddy et al., 2015). While straw mulch usually reduces soil evaporation and stabilizes soil temperature, hence increasing yield, this effect may depend on the irrigation water input conditions. Two experiments in lowland rice paddies in lao pm tested the effect of rice straw mulch under various water input-standard farmer condition to reduced input condition by using either drip irrigation or lower furrow irrigation water input by increasing the furrow irrigation interval before floweringon growth and yield of sweet corn. The time course of water balance components was determined to elucidate the mechanisms of mulch and water input interaction for row planted maize after rice harvesting (Vial et al., 2015). The method involves performing seed preparation, soil preparation by preventing and treating a weed, seeding, seedling management, irrigation management, fertilizer management and pest control, where seedling density is 33.3 to 36 thousand holes per mu in seeding or the seedling density is 30.5 to 32.6 thousand holes per mu in seeding. Target yield and fertilization weight are determined. Nonflooded irrigation is an important watersaving rice cultivation technology, but little is known on its photosynthetic mechanism. The aims of this work were to investigate photosynthetic characteristics of rice during grain filling stage under three nonflooded irrigation treatments: furrow irrigation with plastic mulching, furrow irrigation with nonmulching, and drip irrigation with plastic mulching. Compared with the conventional flooding treatment, those grown in the nonflooded irrigation treatments showed lower net photosynthetic rate, lower maximum quantum yield, and lower effective quantum yield of psii photochemistry (He et al., 2014).

The grain yield ranged from $3.35 \times 10(3) \mathrm{kg}$ ha(-1) to $6.86 \times 10(3) \mathrm{kg}$ ha(-1) under plastic mulching drip irrigation, which was $19.3-60.31 \%$ lower than that under flooding irrigation. Correlation analysis showed that the roots at the a1 and b1 sites were positively significantly correlated with yield components and aboveground agronomic traits. Therefore, improving root development at the a1 and b1 sites at flowering stage could be a key factor to obtain higher grain yield and good agronomic performance under plastic mulching drip irrigation (He et al., 2013). The experiment demonstrates that the di treatment has greater water saving capacity and lower yield and economic benefit gaps than the fim and fin treatments compared with the cf treatment, and would therefore be a better water-saving technology in areas of water scarcity (He et al., 2015). Under non-flooded irrigation, root length was significantly reduced with more roots distributed in deep soil layers compared with the conventional flooding treatment; the drip irrigation treatment had more roots in the topsoil layer than the fim and fin treatments (Chen et al., 2015). The weeding method involves spraying the fencers and harrowing with soil sealing agent before seedling in 
rice drip irrigation planting. The rice is planted by process of the drip irrigation under the film after spraying the fencers with soil sealing agent for 5-7 days. The fencers are sprayed with herbicide after seeding in rice drip irrigation planting under a film when a rice seedling has 3-4 leaves.

In order to enhance the productivity of aerobic rice from present yield level, a production technology which has proved beneficial in increasing the productivities of both grain and water. Disclosed is combined effect of scheduling irrigation at $125 \%$ pan evaporation, application of $100 \%$ recommended doses of nitrogen, phosphorus and potassium (npk) fertilizers, azophosmet and humic acid through drip system. It is proved that drip fertigation technology is beneficial in boosting grain yield coupled with the increased values for water productivity besides improving the fertilizer use efficiency (Arulmozhiselvan, 2009). Drip irrigation is the future of irrigated agriculture, which needs to be strengthened by optimizing the technology for different crops (Sharda et al., 2016).

(Irmak, S. et al.,2014) evaluated the relative evaporative losses and water balance components in two soybean (Glycine max (L.) Merr.) fields under subsurface drip irrigation and center pivot irrigation systems in south-central Nebraska. Evaporation losses were estimated as the difference between measured evapotranspiration and estimated transpiration. Average soil water content in the crop root zone and effective rainfall were estimated using the water balance method.

Soybean (Glycine max) is one of the most important legume crops which fix atmospheric nitrogen in symbiotic association with bacteria through nodules. A study was conducted to investigate the effect of molybdenum and preinoculation of Rhizobium on biological nitrogen fixation and yield of soybean under drip irrigation system (Kanaan et al., 2013).

The growth and yield potential of soybean and the effects of mulching on desert sand were evaluated in relation to $\mathrm{N}$ accumulation in nodules. It was concluded that nitrogen fertilization improves the nutraceutical properties of soybean, although its effect depends on the activity of the isoflavone biosynthetic pathway and the concurrent extent of seed bulging (Vamerali et al., 2012).

A field experiment conducted during 2009 and 2010 at the research farm of the Indian Agricultural Research Institute, New Delhi to study the performance of soybean as influenced by the intercropping of cereals, viz. maize (Zea mays L.), sorghum (Sorghum bicolor (L.) Moench.) and pearl millet (Pennisetum glaucum L.) with 0, 50, 75 and $100 \%$ of their respective recommended dose of N (RDN) levels. The highest gross returns, net returns, B: $\mathrm{C}$ ratio and soybean equivalent yield (SEY) were observed under soybean+maize intercropping system along with $100 \%$ RDN to intercropped maize in both the years of experimentation (Layek et al., 2015). Soybean grown under soybean-wheat-mungbean system had significantly higher total uptake $\mathrm{N}$ and K over soybean-wheat-fallow system (Prajapa et al., 2015). Impact of short-term zero tillage is short lived for favourable soil health and root parameters when skipping with conventional tillage (Rajkumar et 1., 2015).

The water requirement of soybean and wheat estimated by Penmann-Monteith method was in close agreement $(-2.58 \%$ and $9.26 \%$ deviation) with the measured average water requirement (401.6 and $352.2 \mathrm{~mm}$ ) respectively followed by Hargreaves method for Bhopal district (Singh et al., 2015). Sharma et al. (2015) IP of resident AM fungi in soybean rotation involving maize in conservation tillage was found to be highly correlated ( $r=0.96$ to 0.99 ) with grain yield of soybean and maintaining higher 
organic carbon which indicates the functioning of resident AM fungi in enhancing the soybean yield.

Rice (Oryza sativa L.) and soybean (Glycine Max (L.) Merr.) crops were grown in 2013-2016 to determine effect of drip irrigation in the different variants water levels on growth and productivity under conditions of the south-east of Kazakhstan.

\section{Material and Methods}

To solve objective solutions were carried out one-factorial and multiple-factoral field experiments on a demonstration site of the Center of distribution "Ushkonyr" of the Kazakh scientific research institute of agriculture and plant growing (Figure 1, Tables 1-4).

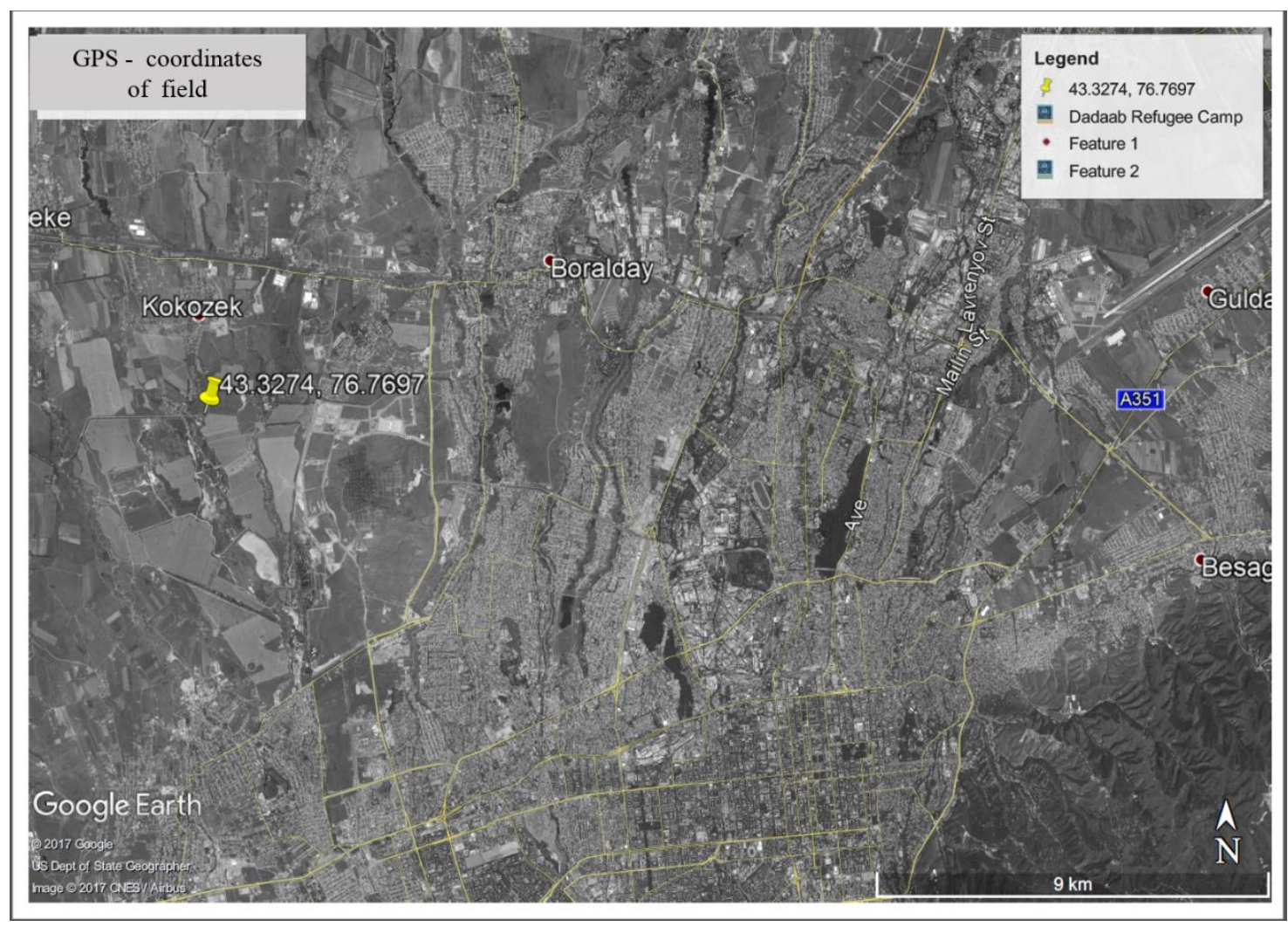

Figure 1. Map of research area

\section{Experiment schemes}

\section{Experiment 1}

The total area of the experiment is 0,15 hectares. The area of soil lots is $40-50$ sq.m, replication is three staged. A fertilizer ground $-\mathrm{N}_{120} \mathrm{P}_{45}$. 
Table 1. Studying of ways of irrigation and rice seeding

\begin{tabular}{c|c}
\hline Ways of irrigation & Ways of rice seeding \\
\hline $\begin{array}{c}\text { 1.Irrigation of rice by flooding } \\
\text { 2.Surface drip irrigation with mulching film }\end{array}$ & $\begin{array}{c}\text { 1. Drill seeding of rice } \\
\text { 2. A two-row tape seeding } 30 \times 70 \mathrm{~cm} \text { with location } \\
\text { of irrigated tape between lines. Distance between } \\
\text { the irrigation tapes is } 100 \mathrm{~cm} .\end{array}$ \\
3.Subsurface irrigation with mulching film & $\begin{array}{c}\text { 3. A four-row tape seeding 10x20 cm with location } \\
\text { of irrigated tape between lines. Distance between } \\
\text { the irrigation tapes is } 120 \mathrm{~cm} .\end{array}$ \\
\hline
\end{tabular}

\section{Experiment 2}

The total area of the experiment is 0.6 hectares. The area of soil lots is 14 sq.m, replication is three staged. A fertilizer ground $-\mathrm{N}_{120} \mathrm{P}_{45}$.

Table 2. Studying of the rice irrigation mode

\begin{tabular}{c|c|c}
\hline Irrigation time & Irrigation day norm, $\mathbf{~ m}^{\mathbf{3}} \mathbf{h a}$ & $\begin{array}{c}\text { Expense of one dripper, } \\
\mathbf{1 / h o u r}\end{array}$ \\
\hline In the morning & 20 & 0,5 \\
In the afternoon & 40 & 1,0 \\
In the evening & 60 & 1,5 \\
At night & 80 & 2,0 \\
\hline
\end{tabular}

\section{Experiment 3}

The total area of the experiment is 0.04 hectares. The area of soil lots is 14 sq.m, replication is three staged.

Table 3. Studying of ways, doses and terms of introduction of mineral fertilizers under rice drip irrigation

\begin{tabular}{c|c|c|c}
\hline \multirow{2}{*}{$\begin{array}{c}\text { Doses of nitrogen fertilizers, kg of rate of } \\
\text { application on 1 hectare }\end{array}$} & \multicolumn{3}{|c}{$\begin{array}{c}\text { Doses of phosphoric fertilizers, kg of rate of } \\
\text { application on 1 hectare }\end{array}$} \\
\cline { 2 - 4 } & $\mathbf{0}$ & $\mathbf{P 4 5}$ & P90 \\
\hline $\mathrm{N} 0$ & & & \\
$\mathrm{~N} 30+\mathrm{N} 30$ & & & \\
$\mathrm{~N} 30+\mathrm{N} 30+\mathrm{N} 30$ & & & \\
$\mathrm{~N} 30+\mathrm{N} 30+\mathrm{N} 30+\mathrm{N} 30+\mathrm{N} 30+\mathrm{N} 30$ & & & \\
\hline
\end{tabular}

\section{Experiment 4}

The total area of the experiment is 0.04 hectares. The area of soil lots is $40-50$ sq.m, replication is three staged. A fertilizer ground $-\mathrm{N}_{120} \mathrm{P}_{45}$.

Table 4. Studying of reaction of rice grades under drip irrigation

\begin{tabular}{c|c|c|c}
\hline Bakanas $s$ & Marzhan & Regul & Xinjang 13-1834 \\
Aru & Yantar & Leader & \\
Kazniizr 5 & Kaz R-5 & Xinjang 13-7013 & \\
\hline
\end{tabular}


The minimum areas of soil lots are connected with system of drip irrigation in experiments, high cost of materials and equipment.

\section{Technique of carrying out accounts and supervision}

- Phenological supervision over growth and development of plants in the main phases by a technique of State commission on a gradetesting;

- Studying of water and physical and meliorative properties of the soil. The accounting of field viability of seeds by calculation on 4 fixed platforms on 0.25 sq.m on all soil lots at full shoots. The accounting of density of plants standing plants by calculation of quantity of plants with 1 sq.m of a soil lot at the beginning and the end of vegetation of the studied cultures in two-staged replication.

- The accounting of dynamics of accumulation of biomass of plants of the studied cultures in the main phases of their development by selection of plants with 1 sq.m of each soil lot in two-staged replication with measurement of crude and dry weight.

- Water consumption of rice plants was defined by a balance method.

- The accounting of a contamination of crops, disease vulnerability and damageability by pests is carried out by the standard technique (Methodical instructions on monitoring of number of weed plants, pests and developments of diseases, Astana, 2004);

- Sampling for studying of maintenance of nutritious elements in the soil and plants will be carried out on the main growth phases and rice developments.

- Before harvesting from three replications of the experiment sheave samples with 1 sq.m were selected. Basic elements of structure of a rice harvest (quantity of plants, quantity of the general and productive stalks, mass of a sheaf, amount of grains in a whisk, the mass of 1000 grains) are determined by a technique of State commission on a gradetesting (Balashev, 1968);

- The accounting of a harvest is carried out seperately by the SAMPO-250 combine;

- Processing of harvest data according to Dospekhov's technique, 1985;

- Quality of grain by the technique stated in the reference book "Assessment of Quality of Grain", M. V.O "Agropromizdat", 1987;

- Studying of agrochemical properties of the soil by a technique of agrochemical researches. Calculation of economic efficiency is made on the actual costs of unit of the made production from area hectare according to the actual monetary and power costs of cultivation of the studied cultures.

Statistical processing of morphometric indicators was done via standard methods Lakin, 1990. The average number of $\mathrm{M} \pm \mathrm{m}$ was calculated by the Student method. The statistical processing of the data was carried out using Student's t-test for P>0.05.

The system of drip irrigation includes: Irrigation water tank on $36 \mathrm{~m}^{3}$ near the river Kaskelenka (Figure 2). The water pump Pedrollo F 32/200B with a productivity of 50 $\mathrm{m}^{3}$ /hour. A settler on $25 \mathrm{~m}^{3}$ at the height of lower level of $5 \mathrm{~m}$. Sandy strainer (Figure 3). Intake strainer; an injector for additional fertilizing; main pipes; distributive pipes; irrigation tapes with drippers for a surface drip irrigation. 


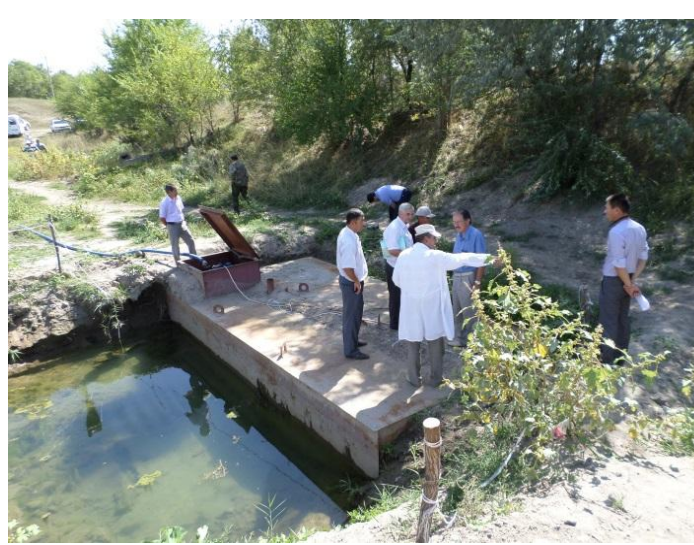

Figure 2. Water intake system for drip irrigation

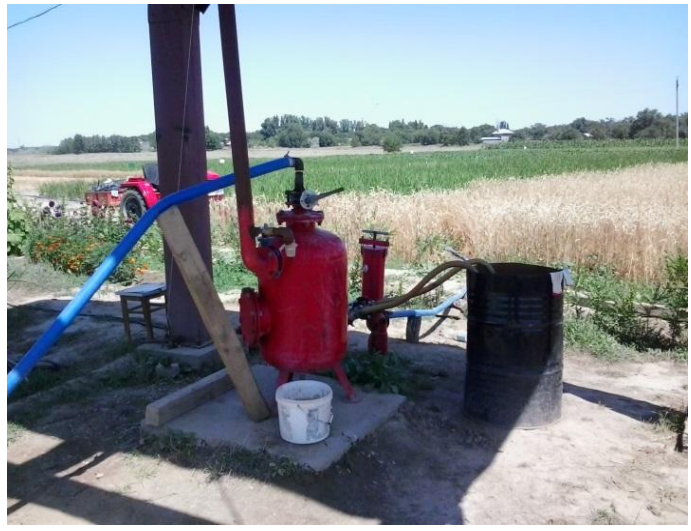

Figure 3. Water cleaning and additional fertilizing system

For preparation of the soil under drip irrigation the general agrotechnology consisted in the following:

- Fall plowing on depth of $25-27 \mathrm{~cm}$.

- Current planning.

- Early-spring braking.

- Introduction of phosphoric fertilizers for creation of grounds.

- Cultivation on depth of 12-15 cm.

- Preseeding processing on depth of crops of seeds.

- Crops of rice and soybean are made by a seeder 2BMJ-4 (People's Republic of China) which carries out simultaneous laying of a drip tape, a tension of the mulching film, seal of seeds over a film and a packing with filling of the soil (Figures 4-5).

- Norm of seeding- 15-30 kg/hectare depending on ways of crops.

- Additional fertilizing was made by ammonium nitrate with irrigation water of drip irrigation, schemes of the experiments: the first - at the beginning of tillering, the second - in a phase of a full tillering, the third - in a booting phase, the fourth - in an ear emergence phase, the fifth - in a phase of dairy grain ripeness.

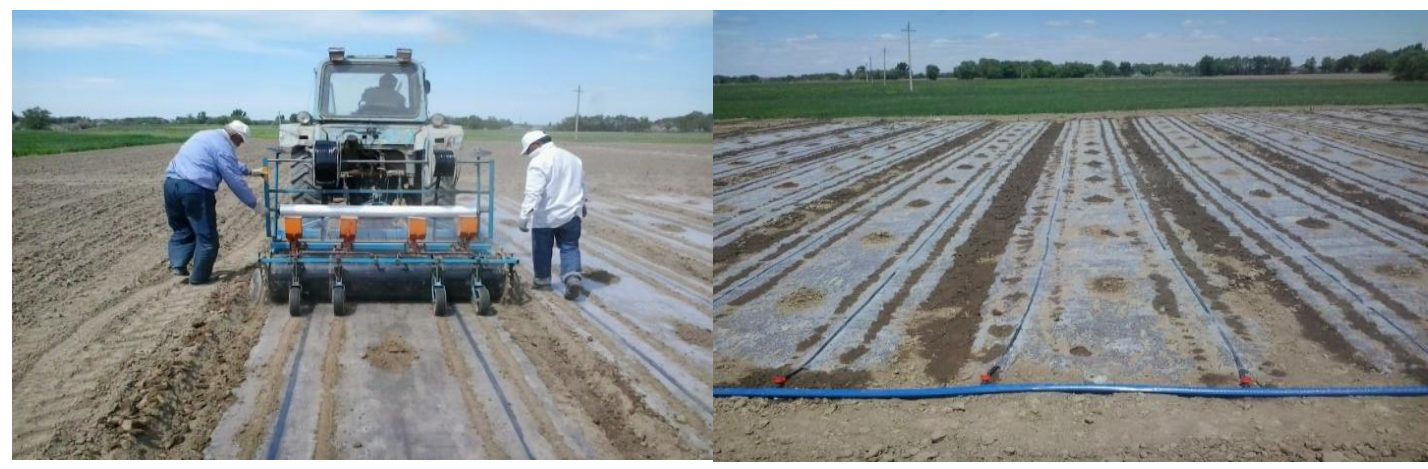

Figure 4. Double-row rice sowing with

Figure 5. Drip irrigation system laying of both irrigation tape and tensioning of the film 
Harvesting was carried out by direct combining SAMPO-250 (Figures 6-7).

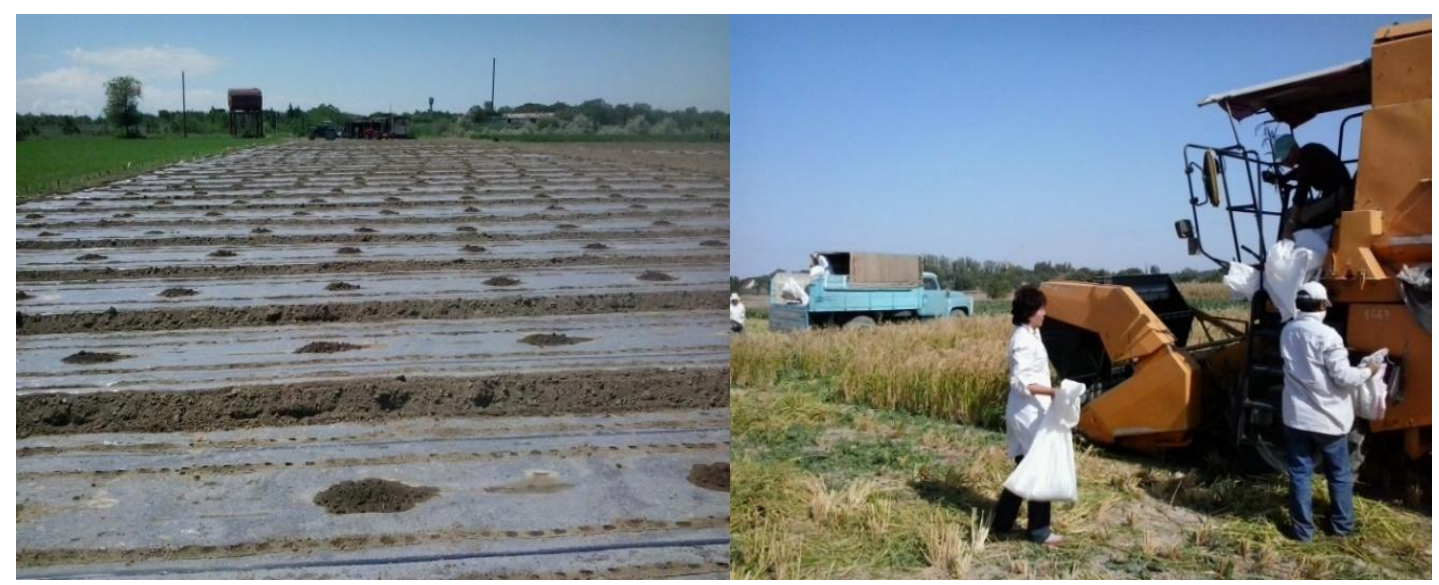

Figure 6. Look of the experiment field after seeding

Figure 7. Plot costing of harvesting with a combine

\section{Agrophysical nature of the soil}

Drip irrigation has positively influenced the maintenance of water-stable aggregate $(>0,25 \mathrm{~mm})$ in the above-mentioned soils under the studied cultures. So, their quantity from before drip irrigation and after that has increased in an arable layer of earth by 0.8 $3.3 \%$, at maximum increase under crops of soy without lamina with plowing on the 22$25 \mathrm{~cm}-$ by $3.3 \%$ and at minimum - under crops of oats with plowing on the 22-25th by $0.8 \%$ and in subarable by $0.6-3.8 \%$ at the greatest under crops of also soy without lamina with plowing on the $22-25$ th - by $3.8 \%$ and the smallest - under crops of sugarbeet under lamina with disking on the 8 -10th - by $0.6 \%$ (Table 5).

Definition and assessment of density of the light brown irrigated soils in May of reporting year demonstrates that the volume mass of $0-40 \mathrm{~cm}$ of a layer under various cultures before drip irrigation which can be accepted as initial fluctuated in the range of $1.22-1.29 \mathrm{~g} / \mathrm{cm}^{3}$. Indicators of volume mass of the specified layer of earth after carrying out a series of drip waterings have raised in September under the studied cultures up to $1.29-1.45 \mathrm{~g} / \mathrm{cm}^{3}$ (Table 6).

Table 5. Agronomical valuable and water-stable aggregates in a foothill zone of Zailiysky Alatau, \% of 2016

\begin{tabular}{c|c|c|c|c}
\hline \multirow{2}{*}{ Culture } & \multicolumn{2}{c|}{$\begin{array}{c}\text { Agronomical water- } \\
\text { Stable aggregates, \% }\end{array}$} & \multicolumn{2}{c}{ Water-stable aggregates, } \\
\cline { 2 - 5 } & $\mathbf{0 - 2 0}$ & $\mathbf{2 0 - 4 0}$ & $\mathbf{0 - 2 0}$ & $\mathbf{2 0 - 4 0}$ \\
\hline $\mathbf{1}$ & $\mathbf{2}$ & $\mathbf{3}$ & $\mathbf{4}$ & $\mathbf{5}$ \\
\hline \multicolumn{4}{|c|}{ May, 26 } \\
\hline Rice-1, plwng-22-25 cm & 58 & 65 & 6.4 & 7.8 \\
Rice-2, plwng-22-25 cm & 53 & 61 & 6.9 & 8.6 \\
Rice-3, plwng-22-25 cm & 52 & 64 & 7.5 & 9.5 \\
Rice under lamina,plwng-22-25 cm & 52 & 55 & 8.3 & 10.6 \\
Soy without lamina,plwng-22-25cm & 51 & 67 & 8.4 & 8.8 \\
Soy under lamina,plwng-22-25 cm & 60 & 66 & 8.8 & 10.4 \\
Sugarbeet under lamina,plwng-22-25 cm & 55 & 63 & 6.9 & 9.4 \\
Sugarbeet without lamina,plwng-22-25 cm & 43 & 57 & 7.2 & 9.0
\end{tabular}


Sugarbeet under lamina, untouched

Sugarbeet without lamina, untouched

Rice under lamina, untouched

Rice without lamina, untouched

\begin{tabular}{l|l|l|c}
59 & 65 & 7.2 & 8.1 \\
44 & 64 & 7.5 & 10.1 \\
61 & 64 & 5.4 & 6.4 \\
52 & 60 & 7.4 & 10.3
\end{tabular}

Rice-1, plwng-22-25 cm

Rice-2, plwng-22-25 cm

Rice-3, plwng-22-25 cm

Rice under lamina,

Soy without lamina,

Soy under lamina,

Sugarbeet under lamina

Sugarbeet without lamina

Sugarbeet under lamina, untouched

Sugarbeet without lamina ,untouched

Rice under lamina, untouched

Rice without lamina, untouched

\section{mber, 6}

\begin{tabular}{l|l|c|c|}
\hline 63 & 57 & 8.9 & 9.6 \\
65 & 60 & 9.2 & 10.5 \\
69 & 62 & 9.7 & 11.1 \\
68 & 61 & 10.2 & 11.2 \\
73 & 66 & 11.7 & 12.6 \\
72 & 65 & 10.9 & 12.8 \\
70 & 64 & 8.4 & 11.2 \\
69 & 59 & 9.0 & 10.8 \\
68 & 60 & 8.3 & 8.7 \\
67 & 62 & 8.9 & 10.9 \\
68 & 43 & 7.7 & 8.3 \\
69 & 61 & 9.3 & 11.6
\end{tabular}

Table 6. Changes of volume mass of the soil under the studied cultures in a foothill zone of Zaiylisky Alatau, $\mathrm{g} / \mathrm{m}^{3}$

\begin{tabular}{|c|c|c|c|c|c|c|}
\hline \multirow{2}{*}{ Culture } & \multirow{2}{*}{ Tilling } & \multicolumn{5}{|c|}{ Horizone } \\
\hline & & 0-10 & $10-20$ & $20-30$ & $30-40$ & $0-40$ \\
\hline 1 & 2 & 3 & 4 & 5 & 6 & 7 \\
\hline \multicolumn{7}{|c|}{ May, 26} \\
\hline Rice without lamina & \multirow{6}{*}{$\begin{array}{c}\text { Moldboard } \\
\text { plowing+ } \\
\text { preseeding } \\
\text { treatment }\end{array}$} & 1.15 & 1.21 & 1.28 & 1.32 & 1.24 \\
\hline Rice under lamina & & 1.17 & 1.23 & 1.29 & 1.31 & 1.25 \\
\hline Soy without lamina & & 1.14 & 1.25 & 1.28 & 1.29 & 1.24 \\
\hline Soy under lamina & & 1.13 & 1.20 & 1.27 & 1.30 & 1.23 \\
\hline Sugarbeet under lamina & & 1.15 & 1.23 & 1.27 & 1.31 & 1.24 \\
\hline \multirow{2}{*}{$\begin{array}{l}\text { Sugarbeet without lamina } \\
\text { Sugarbeet under lamina }\end{array}$} & & 1.17 & 1.22 & 1.25 & 1.28 & 1.23 \\
\hline & \multirow{4}{*}{$\begin{array}{l}\text { Preseeding } \\
\text { treatment }\end{array}$} & 1.18 & 1.25 & 1.32 & 1.29 & 1.26 \\
\hline Sugarbeet without lamina & & 1.23 & 1.27 & 1.30 & 1.32 & 1.28 \\
\hline Rice under lamina & & 1.22 & 1.26 & 1.33 & 1.35 & 1.29 \\
\hline Rice without lamina & & 1.20 & 1.25 & 1.30 & 1.33 & 1.27 \\
\hline \multicolumn{7}{|c|}{ September, 6} \\
\hline Rice without lamina & & 1.23 & 1.30 & 1.39 & 1.44 & 1.34 \\
\hline Rice under lamina & \multirow{5}{*}{$\begin{array}{c}\text { Moldboard } \\
\text { plowing+ } \\
\text { preseeding } \\
\text { treatment }\end{array}$} & 1.24 & 1.28 & 1.37 & 1.43 & 1.33 \\
\hline Soy without lamina & & 1.27 & 1.48 & 1.46 & 1.51 & 1.43 \\
\hline Soy under lamina & & 1.30 & 1.50 & 1.49 & 1.51 & 1.45 \\
\hline Sugarbeet under lamina & & 1.25 & 1.28 & 1.35 & 1.40 & 1.32 \\
\hline \multirow{5}{*}{$\begin{array}{l}\text { Sugarbeet without lamina } \\
\text { Sugarbeet under lamina } \\
\text { Sugarbeet without lamina } \\
\text { Rice under lamina } \\
\text { Rice without lamina }\end{array}$} & & 1.20 & 1.26 & 1.34 & 1.35 & 1.29 \\
\hline & \multirow{4}{*}{$\begin{array}{l}\text { Preseeding } \\
\text { treatment }\end{array}$} & 1.43 & 1.57 & 1.36 & 1.32 & 1.42 \\
\hline & & 1.42 & 1.58 & 1.34 & 1.26 & 1.40 \\
\hline & & 1.29 & 1.43 & 1.45 & 1.31 & 1.37 \\
\hline & & 1.27 & 1.41 & 1.42 & 1.30 & 1.35 \\
\hline
\end{tabular}




\section{Agrochemical nature of the soil (Table 7)}

Table 7. Key indicators of fertility of the soil of sugarbeet in the foothill irrigated zone of Zailiysky Alatau, 2016

\begin{tabular}{|c|c|c|c|c|c|c|c|c|}
\hline $\begin{array}{l}\text { Ways of } \\
\text { irrigation }\end{array}$ & Tilling & 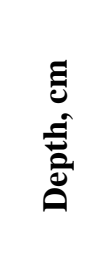 & 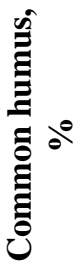 & 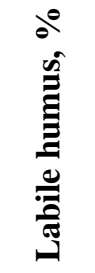 & 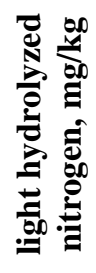 & 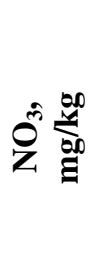 & 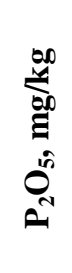 & 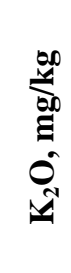 \\
\hline 1 & 2 & 3 & 4 & 5 & 6 & 7 & 8 & 9 \\
\hline \multicolumn{9}{|c|}{ May (26.05.) } \\
\hline \multirow{12}{*}{$\begin{array}{l}\text { Ridge-and- } \\
\text { furrow } \\
\text { irrigation } \\
\text { Drip } \\
\text { Irrigation } \\
\text { Drip } \\
\text { irrigation } \\
\text { under lamina } \\
\text { Ridge-and- } \\
\text { furrow } \\
\text { irrigation } \\
\text { Drip } \\
\text { irrigation } \\
\text { Drip } \\
\text { irrigation } \\
\text { under lamina } \\
\end{array}$} & \multirow{6}{*}{$\begin{array}{l}\text { Preseeding } \\
\text { treatment }\end{array}$} & \multirow{2}{*}{$\begin{array}{c}0-20 \\
20-40\end{array}$} & 1.02 & 0.078 & 22.9 & 53 & 320 & 14.3 \\
\hline & & & 1.20 & 0.104 & 21.4 & 67 & 333 & 12.9 \\
\hline & & $0-20$ & 1.24 & 0.104 & 17.4 & 53 & 495 & 50.9 \\
\hline & & $20-40$ & 1.22 & 0.143 & 19.1 & 50 & 391 & 23.5 \\
\hline & & $0-20$ & 1.04 & 0.143 & 14.1 & 50 & 428 & 26.7 \\
\hline & & $20-40$ & 1.08 & 0.091 & 14.8 & 45 & 408 & 26.3 \\
\hline & \multirow{6}{*}{$\begin{array}{l}\text { Moldboard } \\
\text { plowing+ } \\
\text { preseeding } \\
\text { treatment }\end{array}$} & \multirow{2}{*}{$\begin{array}{c}0-20 \\
20-40\end{array}$} & 1.34 & 0.195 & 7.90 & 50 & 462 & 23.5 \\
\hline & & & 1.26 & 0.117 & 12.9 & 45 & 374 & 26.9 \\
\hline & & $0-20$ & 0.96 & 0.156 & 20.4 & 50 & 329 & 31.5 \\
\hline & & $20-40$ & 1.12 & 0.130 & 19.5 & 50 & 304 & 12.9 \\
\hline & & $0-20$ & 1.04 & 0.091 & 15.1 & 45 & 308 & 80.0 \\
\hline & & $20-40$ & 1.06 & 0.169 & 21.9 & 42 & 333 & 26.3 \\
\hline \multicolumn{9}{|c|}{ September (06.09.) } \\
\hline \multirow{12}{*}{$\begin{array}{l}\text { Ridge -and- } \\
\text { furrow } \\
\text { irrigation } \\
\text { Drip } \\
\text { irrigation } \\
\text { Drip } \\
\text { irrigation } \\
\text { under lamina } \\
\text { Ridge -and- } \\
\text { furrow } \\
\text { irrigation } \\
\text { Drip } \\
\text { irrigation } \\
\text { Drip } \\
\text { irrigation } \\
\text { under lamina }\end{array}$} & \multirow{6}{*}{$\begin{array}{l}\text { Preseeding } \\
\text { treatment }\end{array}$} & \multirow{2}{*}{$\begin{array}{c}0-20 \\
20-40\end{array}$} & 1.43 & 0.196 & 7.80 & 45 & 423 & 33.6 \\
\hline & & & 1.41 & 0.154 & 5.00 & 48 & 411 & 41.3 \\
\hline & & $0-20$ & 1.55 & 0.210 & 4.30 & 56 & 387 & 37.8 \\
\hline & & $20-40$ & 1.41 & 0.168 & 6.60 & 50 & 375 & 27.1 \\
\hline & & $0-20$ & 1.20 & 0.224 & 10.0 & 70 & 403 & 38.9 \\
\hline & & $20-40$ & 1.30 & 0.140 & 3.80 & 62 & 379 & 28.5 \\
\hline & \multirow{6}{*}{$\begin{array}{l}\text { Moldboard } \\
\text { plowing+ } \\
\text { preseeding } \\
\text { treatment }\end{array}$} & $0-20$ & 1.43 & 0.126 & 22.4 & 70 & 394 & 18.2 \\
\hline & & $20-40$ & 1.47 & 0.154 & 10.2 & 62 & 408 & 19.3 \\
\hline & & $0-20$ & 1.30 & 0.140 & 8.90 & 78 & 399 & 28.7 \\
\hline & & $20-40$ & 1.37 & 0.112 & 12.9 & 84 & 408 & 19.0 \\
\hline & & $0-20$ & 1.28 & 0.140 & 3.80 & 56 & 261 & 48.3 \\
\hline & & $20-40$ & 1.32 & 0.140 & 7.20 & 62 & 319 & 19.3 \\
\hline
\end{tabular}

\section{Results and Discussions}

Ways of irrigation have significant effect on elements of structure of a rice crop. Drip irrigation with a two-row tape way of crops forms essentially distinct structure of a rice crop in comparison with usual technology of cultivation of rice. As it can be seen from data of Table 1, indicators of the general, and a productive tilling capacity of plants 
raises on 15.17-16.36 units or 7-8 times. At the same time the greatest productive tilling capacity (16.36) is reached under subsurface drip irrigation of rice (Table 8).

Table 8. Structure of a rice harvest depending on ways of irrigation (average for 2013-2014)

\begin{tabular}{|c|c|c|c|c|c|c|}
\hline \multirow[b]{2}{*}{ Ways of irrigation } & \multirow{2}{*}{$\begin{array}{l}\text { Number of } \\
\text { plants, } \\
\text { piece/sq.m }\end{array}$} & \multicolumn{2}{|c|}{ Tilling capacity } & \multirow{2}{*}{$\begin{array}{l}\text { Number of } \\
\text { grains in a } \\
\text { whisk,piece }\end{array}$} & \multirow{2}{*}{$\begin{array}{c}\text { Mass of } \\
1000 \\
\text { grains, } \\
\mathrm{g} \\
\end{array}$} & \multirow{2}{*}{$\begin{array}{l}\text { Proportion } \\
\text { grain/ } \\
\text { straw }\end{array}$} \\
\hline & & general & productive & & & \\
\hline Flooding irrigation & 106 & 2.11 & 1.86 & 39.1 & 32.5 & 0.24 \\
\hline $\begin{array}{l}\text { Surface drip } \\
\text { irrigation with } \\
\text { mulching film }\end{array}$ & 18 & 16.73 & 15.17 & 63.9 & 35.3 & 0.38 \\
\hline $\begin{array}{l}\text { Subsurface drip } \\
\text { irrigation with } \\
\text { mulching film }\end{array}$ & 17 & 18.89 & 16.36 & 62.0 & 34.7 & 0.38 \\
\hline
\end{tabular}

There is a noticeable Influence of drip irrigation on formation of a bigger whisk grains/ear and mass of 1000 grains of rice, that eventually increased in a share of the productive part of a harvest expressed in the ratio 0.38 to 0.24 in control option.

Under drip irrigation depending on ways of crops formation of structural elements of a rice harvest was controversial (Table 9).

The greatest productive tilling capacity and mass of 1000 grains were formed by grades Bakanassky and Yantar, and whisk set of seed by Aru and KAZNIIR 5.

Table 9. Structure of a harvest of rice grades depending on ways of crops under drip irrigation, 2013

\begin{tabular}{|c|c|c|c|c|c|c|c|}
\hline \multirow[b]{2}{*}{ Grades } & \multirow[b]{2}{*}{$\begin{array}{l}\text { Ways of } \\
\text { seeding }\end{array}$} & \multirow[b]{2}{*}{$\begin{array}{c}\text { Number } \\
\text { of plants, } \\
\text { piece/sq. } \\
\text { m }\end{array}$} & \multicolumn{2}{|c|}{ Tilling capacity } & \multirow[b]{2}{*}{$\begin{array}{l}\text { Number of } \\
\text { grains in a } \\
\text { whisk,piece }\end{array}$} & \multirow[b]{2}{*}{$\begin{array}{c}\text { Mass of } \\
1000 \\
\text { grains, g }\end{array}$} & \multirow[b]{2}{*}{$\begin{array}{c}\text { Proportion } \\
\text { grain/ } \\
\text { straw }\end{array}$} \\
\hline & & & ד্ত & $\stackrel{D}{0}_{0}^{0}$ & & & \\
\hline \multirow[t]{2}{*}{ Bakanassky } & 2-row & 19 & 9.95 & 7.37 & 101 & 36.7 & 0.67 \\
\hline & 4-row & 32 & 4.94 & 3.06 & 84 & 35.1 & 0.52 \\
\hline \multirow{2}{*}{ Aru } & 2-row & 18 & 10.4 & 6.61 & 108 & 33.9 & 0.68 \\
\hline & 4-row & 34 & 4.64 & 4.12 & 71 & 34.6 & 0.53 \\
\hline \multirow[t]{2}{*}{ KAZNIIR 5} & 2-row & 16 & 11.12 & 4.38 & 141 & 32.3 & 0.56 \\
\hline & 4-row & 32 & 5.94 & 2.66 & 94 & 30.8 & 0.35 \\
\hline \multirow[t]{2}{*}{ Yantar } & 2-row & 16 & 10.44 & 7.19 & 100 & 34.2 & 0.67 \\
\hline & 4-row & 30 & 4.26 & 3.22 & 85 & 35.4 & 0.42 \\
\hline
\end{tabular}

Increase in irrigating norm of drip irrigation exerts positive impact on formation of rice tilling capacity and mass of 1000 grains (Table 10).

The irrigating norm of drip irrigation of 4000-6000 $\mathrm{m} 3 / \mathrm{hectare}$ was the most rational norm of watering for formation of the largest sizes of structure of a rice harvest. In these conditions the productive tilling capacity has reached 11.75 pieces, and amount of grains in a whisk of 78 pieces. 
At the same time the best time of implementation of drip irrigation showed watering in the afternoon and in the evening. Positive impact of afternoon and evening terms of drip irrigation on an indicator of the general and productive tilling capacity is noted (Table 11).

Table 10. Structure of a rice harvest depending on the mode of drip irrigation (average for 2013-2014)

\begin{tabular}{|c|c|c|c|c|c|c|}
\hline \multirow{2}{*}{$\begin{array}{c}\text { Irrigating } \\
\text { norm } \\
\mathbf{m}^{3} / \text { hectare }\end{array}$} & \multirow{2}{*}{$\begin{array}{c}\text { Number } \\
\text { of plants, } \\
\text { piece/sq.m }\end{array}$} & \multicolumn{2}{|c|}{ Tilling capacity } & \multirow{2}{*}{$\begin{array}{l}\text { Number of } \\
\text { grains in a } \\
\text { whisk, piece }\end{array}$} & \multirow{2}{*}{$\begin{array}{l}\text { Mass of } 1000 \\
\text { grains, } g\end{array}$} & \multirow{2}{*}{$\begin{array}{c}\text { Proportio } \\
\text { n grain/ } \\
\text { straw }\end{array}$} \\
\hline & & general & $\begin{array}{c}\text { productiv } \\
\text { e }\end{array}$ & & & \\
\hline 2000 & 17 & 12.36 & 9.77 & 66.5 & 35.7 & 0.38 \\
\hline 4000 & 15 & 13.43 & 10.40 & 78.0 & 34.2 & 0.35 \\
\hline 6000 & 16 & 13.94 & 11.75 & 71.0 & 35.3 & 0.33 \\
\hline 8000 & 18 & 11.45 & 8.73 & 67.7 & 36.4 & 0.36 \\
\hline
\end{tabular}

Table 11. Structure of a rice harvest depending on time of drip irrigation (2013-2014)

\begin{tabular}{|c|c|c|c|c|c|c|}
\hline \multirow{2}{*}{$\begin{array}{l}\text { Irrigating } \\
\text { norm } \\
\text { m3/hectare }\end{array}$} & \multirow{2}{*}{$\begin{array}{c}\text { Number } \\
\text { of plants, } \\
\text { piece/sq.m }\end{array}$} & \multicolumn{2}{|c|}{ Tilling capacity } & \multirow{2}{*}{$\begin{array}{l}\text { Number of } \\
\text { grains in a } \\
\text { whisk,piece }\end{array}$} & \multirow[b]{2}{*}{$\begin{array}{l}\text { Mass of } 1000 \\
\text { grains, } g\end{array}$} & \multirow{2}{*}{$\begin{array}{c}\text { Proportio } \\
\text { n grain/ } \\
\text { straw }\end{array}$} \\
\hline & & general & $\begin{array}{c}\text { productiv } \\
\text { e }\end{array}$ & & & \\
\hline In the morning & 17 & 11.24 & 9.65 & 70.4 & 37.0 & 0.36 \\
\hline $\begin{array}{l}\text { In the } \\
\text { afternoon }\end{array}$ & 17 & 13.00 & 10.83 & 76.9 & 36.4 & 0.37 \\
\hline In the evening & 18 & 12.67 & 10.39 & 73.5 & 35.5 & 0.32 \\
\hline At night & 17 & 14.12 & 11.95 & 71.8 & 35.6 & 0.39 \\
\hline
\end{tabular}

Significant effect on formation of structure of a harvest renders conditions of mineral food of rice. As it can be seen from Table 12, without fertilizers the productive tilling capacity of plants of rice under drip irrigation did not exceed 9 units.

Use of nitrogen fertilizers in additional fertilizing with irrigation water promotes sharp increase of coefficient of rice tillering, the indicator of the tilling capacity in option with four and five nitric additional fertilizing on ground P90 reaches size of 18.218.7 and a productive tilling capacity of 15.7-17.0 units.

Table 12. Structure of a rice harvest depending on conditions of mineral food under drip irrigation (average for 2013-2014)

\begin{tabular}{|c|c|c|c|c|c|c|}
\hline \multirow[b]{2}{*}{ Fertilizer } & \multirow[b]{2}{*}{$\begin{array}{c}\text { Number of } \\
\text { plants, } \\
\text { piece/sq.m }\end{array}$} & \multicolumn{2}{|c|}{$\begin{array}{c}\text { Tilling } \\
\text { capacity }\end{array}$} & \multirow[b]{2}{*}{$\begin{array}{l}\text { Number of } \\
\text { grains in a } \\
\text { whisk,piece }\end{array}$} & \multirow[b]{2}{*}{$\begin{array}{c}\text { Mass of } \\
1000 \\
\text { grains, g }\end{array}$} & \multirow[b]{2}{*}{$\begin{array}{c}\text { Proportio } \\
\text { n grain/ } \\
\text { straw }\end{array}$} \\
\hline & & ד্তু & 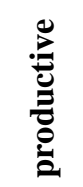 & & & \\
\hline No fertilizing & 15 & 11.5 & 8.2 & 57.5 & 35.5 & 0.47 \\
\hline $\mathrm{N} 30+\mathrm{N} 30$ & 17 & 11.9 & 9.8 & 68.7 & 34.9 & 0.51 \\
\hline $\mathrm{N} 30+\mathrm{N} 30+\mathrm{N} 30$ & 17 & 13.0 & 11.5 & 61.5 & 34.9 & 0.37 \\
\hline $\mathrm{N} 30+\mathrm{N} 30+\mathrm{N} 30+\mathrm{N} 30$ & 15 & 17.9 & 15.9 & 58.4 & 35.1 & 0.38 \\
\hline $\mathrm{N} 30+\mathrm{N} 30+\mathrm{N} 30+\mathrm{N} 30+\mathrm{N} 30$ & 19 & 14.6 & 13.2 & 60.3 & 36.1 & 0.36 \\
\hline $\mathrm{P} 45$ & 17 & 9.8 & 8.5 & 80.9 & 34.0 & 0.65 \\
\hline $\begin{array}{l}\text { Ground1+ } \\
\text { N30+N30 }\end{array}$ & 16 & 14.6 & 12.0 & 65.6 & 35.1 & 0.46 \\
\hline
\end{tabular}




\begin{tabular}{c|c|c|c|c|c|c} 
Ground1+ & 16 & 15.6 & 11.4 & 68.0 & 36.1 & 0.45 \\
$\begin{array}{c}\text { N30+N30+N30 } \\
\text { Ground1+ }\end{array}$ & 16 & 15.3 & 13.1 & 55.3 & 36.6 & 0.37 \\
N30+N30+N30+N30 & 18 & 13.39 & 11.1 & 92.2 & 33.1 & 0.39 \\
$\begin{array}{c}\text { Ground 1+ } \\
\text { N30+N30+N30+N30+N30 }\end{array}$ & 18 & 13.2 & 11.8 & 51.3 & 35.7 & 0.29 \\
P90 - Ground 2 \\
$\begin{array}{c}\text { Ground 2+ } \\
\text { N30+N30 }\end{array}$ & 19 & 15.4 & 11.1 & 55.9 & 35.5 & 0.33 \\
$\begin{array}{c}\text { Ground 2+ } \\
\text { N30+N30+N30 }\end{array}$ & 17 & 15.0 & 13.2 & 61.1 & 33.2 & 0.34 \\
$\begin{array}{c}\text { Ground 2+ } \\
\text { N30+N30+N30+N30 }\end{array}$ & 17 & 18.2 & 15.7 & 66.7 & 37.0 & 0.38 \\
$\begin{array}{c}\text { Ground 2+ } \\
\text { N30+N30+N30+N30+N30 }\end{array}$ & 18 & 18.7 & 17.0 & 63.7 & 33.6 & 0.39 \\
\hline
\end{tabular}

Results of the accounting of a harvest of the first year of researches (Table 13) show that in option with a usual way of an irrigation with flooding with introduction of average doses of fertilizers the harvest of rice of $29.1 \mathrm{c} /$ hectare are received. In options on studying of drip irrigation ways without the mulching film crops of rice were unaccountable, have grown with weeds and at a booting phase growth of plants has stopped. Mechanical and chemical ways of control of weeds in these options are not effective. Therefore, in the next years options of drip irrigation without the mulching film are excluded from experience.

Table 13. Crop yield of rice depending on ways of irrigation, c/hectare

\begin{tabular}{c|c|c|c|c}
\hline Ways of irrigation & $\mathbf{2 0 1 2}$ & $\mathbf{2 0 1 3}$ & $\mathbf{2 0 1 4}$ & Average \\
\hline Flooding irrigation & 29.1 & 17.4 & 32.2 & 26.2 \\
Surface drip irrigation & 0 & - & - & - \\
Surface irrigation with film & 48.5 & 49.3 & 59.4 & 52.4 \\
Subsurface drip irrigation & 0 & - & - & - \\
Subsurface drip irrigation with film & 20.3 & 58.6 & 50.8 & 43.2 \\
P=4.3\% & 3.6 & 4.5 & 4.9 & \\
HCP 0.95=5.1 centners per a hectare & 2.9 & 5.6 & 7.0 & \\
\hline
\end{tabular}

Efficiency of drip irrigation ways by years of researches was ambiguous. In 2012 and 2013 there was an efficiency of surface way of drip irrigation, and in 2013 - subsurface drip irrigation with mulching film. In general, in three years at a usual way of cultivation of rice by flooding 26.2 c/hectare had been received, and at ways of drip irrigation with a film 43.2-52.4 c/hectare of a grain yield of rice are received. The greatest and most stable grain yields of rice by years have been received under surface drip irrigation with use of the mulching film.

In 2013 there were formed experiment options with 4-row tape way of seeding. Results of the experiment show that the new way of seeding had no advantage comparing with 2-row tape seeding. As it is seen from data of Table 14, the new way of seeding was effective only under drip irrigation of an early ripe grade Aru. From the studied grades the greatest productivity in Almaty region showed the grade Bakanassky under drip irrigation with 2-row tape seeding. 
Table 14. Productivity of grades of rice depending on ways of crops under drip irrigation, c/hectare

\begin{tabular}{c|c|c|c}
\hline \multirow{2}{*}{ Сорта } & \multicolumn{3}{|c}{ Ways of seeding } \\
\cline { 2 - 4 } & \multicolumn{2}{|c}{ 2-row tape } & 4-row tape \\
\cline { 2 - 4 } & $\mathbf{2 0 1 2}$ & $\mathbf{2 0 1 3}$ & $\mathbf{2 0 1 3}$ \\
\hline Bakanassky & 48.5 & 51.2 & 28,7 \\
Aru & 42.1 & 38.7 & 35,8 \\
KAZNIIR 5 & 46.6 & 34.4 & 21,3 \\
Yantar & 33.5 & 35.5 & 26,8 \\
P=4.9\% & 3.4 & 6.4 & \\
HCP 0.95=4.0, centners per a hectare & 2.6 & 5.4 & \\
\hline
\end{tabular}

Studying of the mode of rice drip irrigation shows that relatively big crops of rice are received when watering by irrigation norm $4000-6000 \mathrm{~m} 3 /$ hectare (Table 15) in the afternoon and in the evening.

Relatively low productivity of rice at the morning term of drip irrigation can be explained by low temperature of irrigation water. Whereas at the afternoon term of watering, water significantly heats up when passing through a drip tape, at evening watering irrigation water heats up in the tank.

Table 15. Productivity of rice depending on the mode of drip irrigation, c/hectare

\begin{tabular}{|c|c|c|c|c|}
\hline \multirow{2}{*}{ Irrigating norm, $\mathrm{m}^{3} / \mathrm{ha}$} & \multicolumn{4}{|c|}{ Irrigation time } \\
\hline & morning & afternoon & evening & night \\
\hline \multicolumn{5}{|c|}{2013} \\
\hline 2000 & 39.2 & 39.9 & 42.6 & 46.8 \\
\hline 4000 & 43.6 & 43.3 & 39.2 & 47.6 \\
\hline 6000 & 43.8 & 40.0 & 46.3 & 50.0 \\
\hline 8000 & 38.7 & 39.2 & 42.4 & 47.1 \\
\hline \multicolumn{5}{|c|}{$\mathrm{P}=4.7 \%, \mathrm{HCP}_{0.95}=4.9 \mathrm{c} / \mathrm{ha}$} \\
\hline \multicolumn{5}{|c|}{2014} \\
\hline 2000 & 27.1 & 34.6 & 37.6 & 36.2 \\
\hline 4000 & 28.5 & 55.0 & 57.1 & 43.0 \\
\hline 6000 & 34.7 & 53.8 & 60.9 & 57.0 \\
\hline 8000 & 34.8 & 50.8 & 58.7 & 48.0 \\
\hline \multicolumn{5}{|c|}{$\mathrm{P}=5.4 \%, \mathrm{HCP}_{0.95}=5.8 \mathrm{c} / \mathrm{ha}$} \\
\hline \multicolumn{5}{|c|}{ Average for 2013-2014 } \\
\hline 2000 & 33.2 & 37.3 & 40.1 & 41.5 \\
\hline 4000 & 36.1 & 49.2 & 48.2 & 45.3 \\
\hline 6000 & 39.3 & 46.9 & 53.6 & 53.5 \\
\hline 8000 & 36.8 & 45.0 & 50.6 & 47.6 \\
\hline
\end{tabular}

Studying of efficiency of nitric additional fertilizing under drip irrigation on three phosphoric food (Table 16) shows that without introduction of phosphoric fertilizers of an increase of a harvest from nitric additional fertilizing makes 6.6-13.1 c/hectare. On this background two additional fertilizing by drip irrigation on $30 \mathrm{~kg}$ on hectare are rational and the harvest reaches $46.2 \mathrm{c} /$ hectare.

Efficiency of nitrogen fertilizers was most accurately shown in 2014, when additional fertilizing from nitric have made 16.6-36.9 c/hectare depending on a phosphoric ground and number of nitric additional fertilizing. At the same time nitrogen share factor in formation of a harvest has made $70 \%$, to $4 \%$ of phosphorus share. 
Table 16. Productivity of rice depending on conditions of mineral food under drip irrigation, c/hectare

\begin{tabular}{|c|c|c|c|}
\hline \multirow{2}{*}{ Level of nitric feeding } & \multicolumn{3}{|c|}{ Level of phosphoric feeding } \\
\hline & $\mathbf{0}$ & $\mathbf{P 4 5}$ & $\mathbf{P 9 0}$ \\
\hline \multicolumn{4}{|c|}{2013} \\
\hline N0 & 33.1 & 43.2 & 45.1 \\
\hline $\mathrm{N} 30+\mathrm{N} 30$ & 46.2 & 42.5 & 55.8 \\
\hline $\mathrm{N} 30+\mathrm{N} 30+\mathrm{N} 30$ & 41.8 & 54.6 & 55.4 \\
\hline $\mathrm{N} 30+\mathrm{N} 30+\mathrm{N} 30+\mathrm{N} 30$ & 39.7 & 44.6 & 44.5 \\
\hline $\mathrm{N} 30+\mathrm{N} 30+\mathrm{N} 30+\mathrm{N} 30+\mathrm{N} 30$ & 39.8 & 38.0 & 46.0 \\
\hline \multicolumn{4}{|c|}{$\mathrm{P}=4.4 \%, \mathrm{HCP}_{0.95}=4.7 \mathrm{c} / \mathrm{ha}$} \\
\hline \multicolumn{4}{|c|}{2014} \\
\hline N0 & 23.5 & 40.8 & 37.2 \\
\hline $\mathrm{N} 30+\mathrm{N} 30$ & 36.0 & 42.0 & 35.9 \\
\hline $\mathrm{N} 30+\mathrm{N} 30+\mathrm{N} 30$ & 37.6 & 39.1 & 48.2 \\
\hline $\mathrm{N} 30+\mathrm{N} 30+\mathrm{N} 30+\mathrm{N} 30$ & 55.2 & 49.4 & 48.3 \\
\hline $\mathrm{N} 30+\mathrm{N} 30+\mathrm{N} 30+\mathrm{N} 30+\mathrm{N} 30$ & 58.2 & 57.4 & 74.1 \\
\hline \multicolumn{4}{|c|}{$\mathrm{P}=5.2 \%, \mathrm{HCP}_{0.95}=5.7 \mathrm{c} / \mathrm{ha}$} \\
\hline \multicolumn{4}{|c|}{ Average for 2013-2014 } \\
\hline N0 & 28.3 & 42.0 & 41.2 \\
\hline $\mathrm{N} 30+\mathrm{N} 30$ & 41.1 & 42.3 & 45.9 \\
\hline $\mathrm{N} 30+\mathrm{N} 30+\mathrm{N} 30$ & 39.7 & 46.9 & 51.8 \\
\hline $\mathrm{N} 30+\mathrm{N} 30+\mathrm{N} 30+\mathrm{N} 30$ & 47.5 & 47.0 & 46.4 \\
\hline $\mathrm{N} 30+\mathrm{N} 30+\mathrm{N} 30+\mathrm{N} 30+\mathrm{N} 30$ & 43.7 & 47.7 & 60.1 \\
\hline
\end{tabular}

In the experience it has been shown that mulch has excellent impact on the growth and development of plants and has a negative impact on the nodule bacteria, that in the early phases provide favorable conditions for growth and development of soybean. In the variant without mulch, which are actively developing nodule bacteria in the initial phase inhibit the growth and development of soybeans, in connection can be noted in the early phases of nodule bacteria are parasitic.

In the literature, there are studies that confirm our data, but we note that in the version with a modern film developing nodule bacteria, but then their parasitism is not particularly stands out since, by the time the plant is well adapted in a supportive environment.

The observation showed that good loosening and sheeting occurs during branching, especially in the film version, the early spring foil retains not only moisture, but also allows heat in the field sites to clearly demonstrate good growth in the embodiment with the film, this proves a favorable film. The effect at drip irrigation, drip irrigation affects high productivity in comparison with traditional irrigation, since in experimental plots where the furrow is traditionally watered, soybean does not receive Due to the fact that water is not fully used in the direction, and here to save water. It is worth mentioning the procedure that should be implemented in all regions where there is a shortage of water, thus ensuring maximum productivity, not just soybean, And in many cultures.

In terms of the fact that water saving is due to the films also need to emphasize that the film under the water does not evaporate into the air and vaporized water is supplied to the reverse order of the plant. This not only saves water, but also keeps the heat under the film, which in the cold season supports the plants. In the Almaty region in the south-east of Kazakhstan the climate is not homogeneous, as the weather is variable, in this regard, the film is a necessity. In the Figure 8 soybean were grown without mulch by drip irrigation. In the Figures 9-10 soybean were grown with mulch under drip irrigation. 


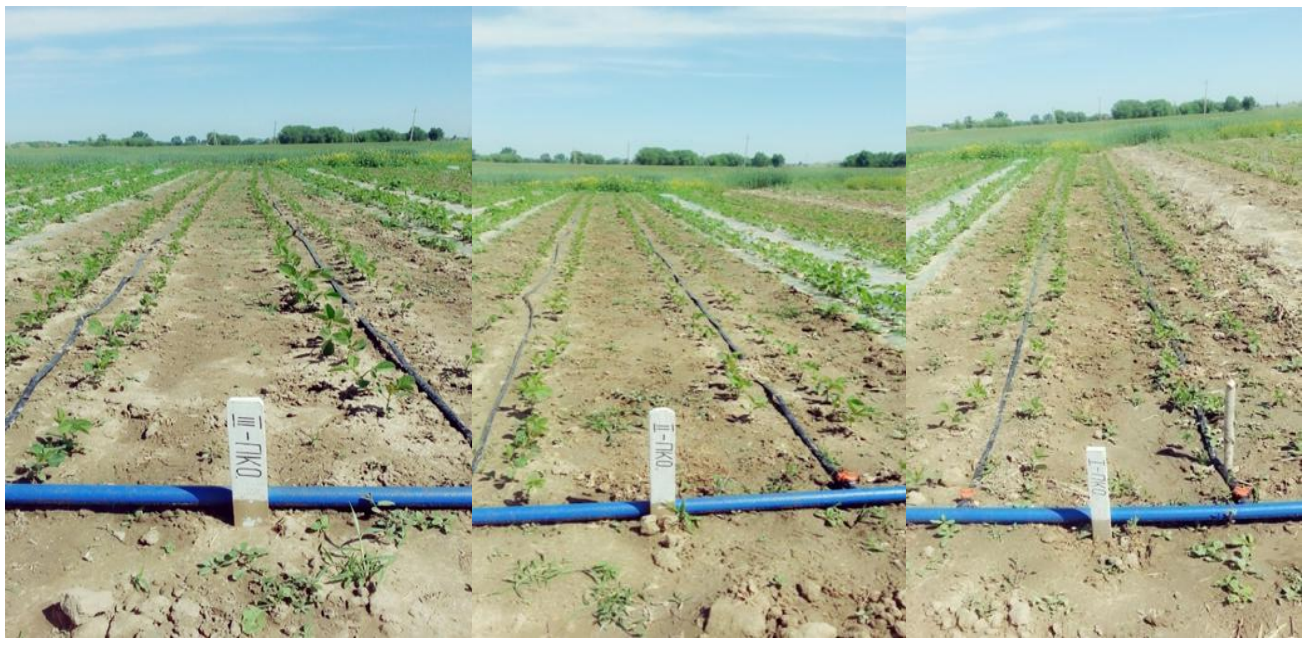

Figure 8. Soybean grown without mulch under drip irrigation

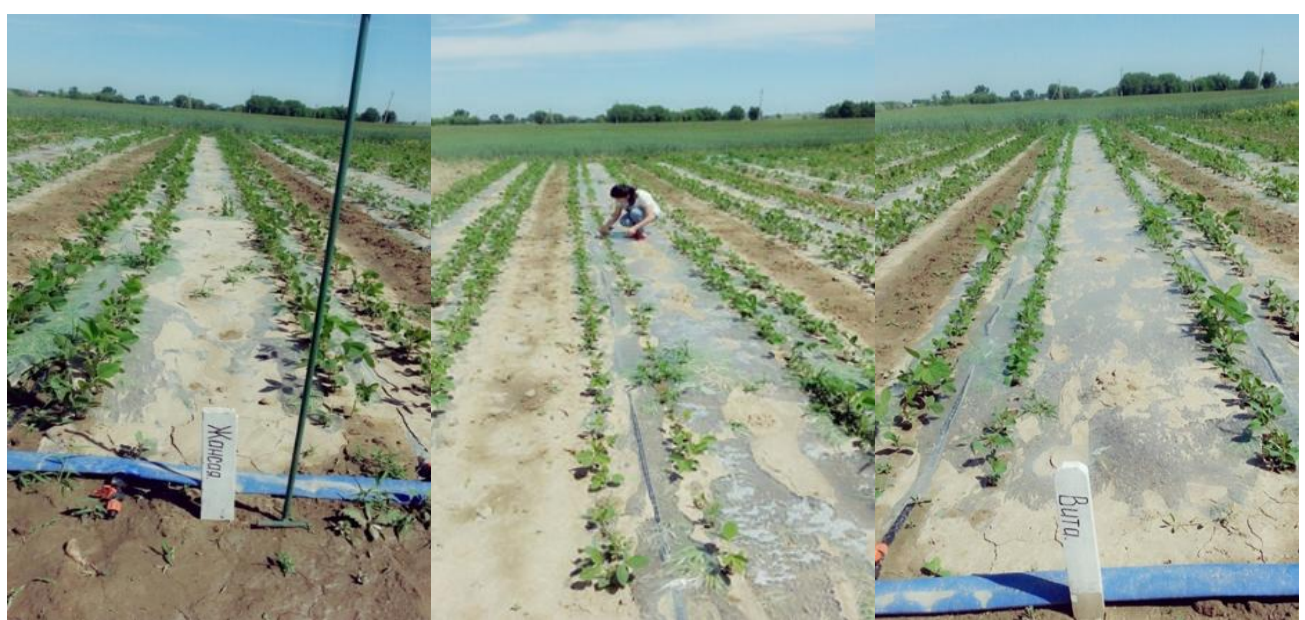

Figure 9. Soybean grown with mulch under drip irrigation

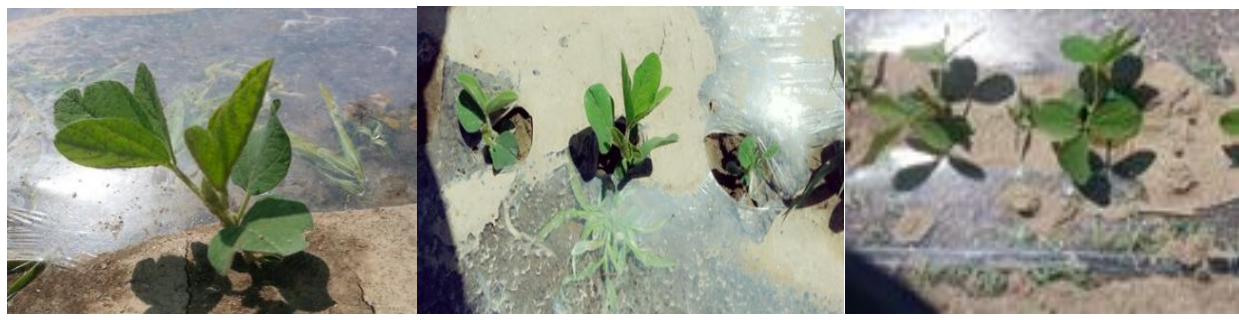

Figure 10. Growth and development of soybean under mulch

Intensive growth and development of soybean plants during vegetation with formation of bigger biomass of plants, a leaf surface and basic elements of harvest structure eventually led to formation of more crops. It should be noted that the bigger soybean harvest was in option with surface drip irrigation on 3.6-9.2 c/hectare. Despite the bad weather conditions for growth and development of soy in the southeast of Kazakhstan, we have got a big crop (42.2 c/hectare) in option with use of the mulching 
film. At the same time the most effective way of drip irrigation was the surface one (Abdukadirova et al., 2016). As a result of research, there has been revealed the most acceptable option of cultivation and irrigation for the Kazakhstan soy gradessurface drip irrigation with the mulching film (Table 17), and also the grades Lastochka and Dikovit showed the highest results in harvest in three years.

Table 17. Structure of the harvest of soy grades under drip irrigation, 2013-2015

\begin{tabular}{c|c|c|c|c|c}
\hline Grades & $\begin{array}{c}\text { Amount of } \\
\text { plants, } \\
\text { piece/sq.m }\end{array}$ & $\begin{array}{c}\text { Amount of } \\
\text { branches, } \\
\text { piece }\end{array}$ & $\begin{array}{c}\text { Amount of } \\
\text { beans in 1 } \\
\text { plant, piece }\end{array}$ & $\begin{array}{c}\text { Mass 1000 } \\
\text { grains, g }\end{array}$ & $\begin{array}{c}\text { Biological } \\
\text { harvest, } \\
\text { h/sq.m }\end{array}$ \\
\hline Zhalpaksay & $20 \pm 2.2$ & $8.2 \pm 0.9$ & $52 \pm 14.5$ & $146 \pm 0.9$ & $467 \pm 19.8$ \\
Zhansaya & $20 \pm 2.9$ & $9.4 \pm 1.4$ & $76 \pm 17.8$ & $145 \pm 0.7$ & $660 \pm 20.6$ \\
Lastochka & $20 \pm 3.5$ & $8.8 \pm 1.2$ & $84 \pm 11.6$ & $150 \pm 1.8$ & $760 \pm 17.9$ \\
Vita & $20 \pm 2.7$ & $10.1 \pm 2.3$ & $68 \pm 16.9$ & $150 \pm 1.6$ & $620 \pm 21.8$ \\
Dikovit & $20 \pm 3.0$ & $12.4 \pm 3.4$ & $78 \pm 13.2$ & $156 \pm 2.1$ & $739 \pm 13.5$ \\
\hline
\end{tabular}

Three-year studies have been shown that the use of mulching film in rice and soybean cultures primarily contributes to the economic use of resources, as a result of which the growth of weeds is suspended. Since water helps stop the growth of weeds in rice and soybean, the use water saving technologies and mulching film when growing rice and soybean for increase productivity of rice and soybean in Kazakhstan.

For rice in southeastern Kazakhstan under drip irrigation there are 2-row ribbon cultures with a distance between the bands of $70 \mathrm{~cm}$ and rows in the tape of $30 \mathrm{~cm}$. At the same time, the drop band is held within the slots in the belt. According to these results, it is recommended to increase the yield of rice to growth under the drip irrigation of mulch. Comparison of the productivity of soybean varieties showed that productivity in variants with mulch far exceeded variants without mulching.

\section{Conclusions}

Results of three years of researches on studying of rice and soybean drip irrigation efficiency let us make the following conclusions:

- Drip irrigation with application of the mulching film promotes emergence of early and amicable shoots of rice, intensive growth and development of plants, productivity increase.

- Drip irrigation with use of the mulching film at 8-10 times reduces a contamination of crops of rice that allows to exclude application of manual use, mechanical and chemical processing of crops.

- Use of the mulching film under rice drip irrigation promotes creation of the favorable nitric mode of the soil with big accumulation of ammoniac and nitrate nitrogen and mobilization of motile phosphorus.

- The best way of rice crops under drip irrigation is 2-row tape crops with distance between tapes of $70 \mathrm{~cm}$ and a row-spacing in a tape of $30 \mathrm{~cm}$. At the same time the drip tape keeps within row-spacings in a tape.

- Most optimum mode for efficiency of rice was under rice drip irrigation in the evening and night period by irrigating norm of $4-6$ thousand $\mathrm{m}^{3} /$ hectare. The consumption of irrigation water on cultivation of rice is reduced by 5-10 times. 
- Optimum conditions of mineral food of rice under drip irrigation of rice is reached by introduction of phosphoric fertilizers under preseeding cultivation by a dose of $45 \mathrm{~kg}$ on 1 hectare and 4-5 triple nitric additional fertilizing under drip irrigation to a phase of dairy ripeness of rice grain a dose of $30 \mathrm{~kg}$ of on 1 hectare. Efficiency of the introduced fertilizers significantly increases under drip irrigation.

- Drip irrigation with or without mulch was adopted for the experimental plots. The most effective way to combat weeds in soybean crops proved to drip irrigation under mulch film, where the number of weeds in the early growing season did not exceed 36-44 units / $\mathrm{m}^{2}$.

- Despite the prevailing adverse weather conditions for the growth and development of soybean in the south-east of Kazakhstan, we have received a fairly high yield (42.2 tonnes / ha) on a variant using a mulching film.

- The results indicated that use mulch under drip irrigation significantly increase plant growth and production soybean. This increase is due to benefits such as increase in soil temperature, reduced weed pressure, moisture conservation, reduction of certain insect pests, higher crop yields, and more efficient use of soil nutrients.

Acknowledgements. This work was implemented within the scientific project "Development of drip irrigation technology in applying to the main field crops of the irrigated zone of the South and the Southeast of Kazakhstan", UDC 631.1:626.8 (574.51/54), State registration No 0115RK02298. This project was funded by the Ministry of Agriculture of the Republic of Kazakhstan.

\section{REFERENCES}

[1] Abdukadirova, Zh. A., Kurmanbayeva, M. S. et al. (2016): Morphological and anatomical changes of soybean under different conditions of cultivation. - Research Journal of Pharmaceutical, Biological and Chemical Sciences 7(4): 1683-1692.

[2] Abdukadirova, Zh. A., Kurmanbayeva, M. S., Ospanbayev, Zh. O. (2016): Effect of mulch on soybean (Glycine Max L. Merr.) at cultivation under drip Irrigation in the South-east of Kazakhstan. - Biosciences Biotechnology Research Asia 13(2): 751-759.

[3] Arulmozhiselvan, K., Vengatesan, R., Deivana.i, M. (2009): Nutriseed holder technique for increasing nutrient use efficiency and yield under wetland and upland situations in rice and maize. - Research on crops 10(3): 473-480.

[4] Beecher, H. G., Dunn B. W., Thompson, J. A., Humphreys, E. (2006): Effect of raised beds, irrigation and nitrogen management on growth, water use and yield of rice in southeastern Australia. - Australian Journal of Experimental Agriculture 46:1363-1372.

[5] Chen, L., Zhou, X., Chen, Y., Fan, X., Gao, Z., Cheng, H., Qian, G., Yin, Y. (2013): Involves spraying fencers with herbicide after seeding in rice drip irrigation planting under film. - Patent numbers: cn 103141465-a.

[6] Chen, Y., Ruan, M., Guo, Q., Li, Z., Wang, P. (2009): Under film drop irrigation dry farming cultivation method for sowing rice, involves connecting drip irrigation zone with water-transporting system for dripping water and fertilizer in proper time with proper dosage. - Patent numbers: cn101422120-a; cn101422120-b

[7] Coltro, L., Marton, L. F. M., Pilecco, F. P., Pilecco, A. C., Mattei, L. F., (2012): Environmental. Drip fertigation technology for aerobic rice (Oryza sativa). - Patent numbers: in201002138-i4 
[8] Enciso-Medina, et al. (2001): No till and tillage under subsurface drip irrigation. http://goldmine.tamu.edu/agents/files/sub157/Tillage-2years2.html3/8/ 2005

[9] FAO. (2010): Irrigation Water Management: Irrigation methods. Rom: Food and Agriculture Organization of the United Nations (FAO). URL 10

[10] FAO. (2017): Drought characteristics and management in Central Asia and Turkey // FAO Water reports food and agriculture organization of the United Nations. Rome.

[11] Grabow, G. L., Huffman, R. L., Evans, R. O. (2011): SDI Dripline Spacing Effect on Corn and Soybean Yield in a Piedmont Clay Soil. - Journal of Irrigation and Drainage Engineering-Asce 137(1): 27-36.

[12] He, H. B., Ma, F. Y., Ru, J. B. (2013): Rice performance and water use efficiency under plastic mulching with drip irrigation. - Plos one 8(12): 83-103.

[13] He, H. B., Yang, R., Chen, L., Fan, H. (2014): Rice root system spatial distribution characteristics at flowering stage and grain yield under plastic mulching drip irrigation. Journal of animal and plant sciences 24(1): 290-301.

[14] He, H. B., Yang, R., Jia B., Chen, L. (2014): Rice photosynthetic productivity and psii photochemistry under nonflooded irrigation. - The scientific world journal 58: 83-96.

[15] He, H. B., Yang, R., Wu, L. Q., Jia, B., Ma, F. Y. (2016): The growth characteristics and yield potential of rice (Oryza sativa) under non-flooded irrigation in arid region. Annals of Applied Biology 168:337-356.

[16] Hunt, P. G., Stone, K. C., Matheny, T. A. (2011): Double-Cropped Soybean and Wheat with Subsurface Drip Irrigation Supplemented by Treated Swine Wastewater. Communications in Soil Science and Plant analysis 42(22): 2778-2794.

[17] Irmak, A., Singh, R. K., Walter-Shea, E. A. (2011): Comparison and analysis of empirical equations for soil heat flux for different cropping systems and irrigation methods. - Transactions of the Asabe 54(1): 67-80.

[18] Irmak, S. ,Specht, J. E., Odhiambo, L. O., Rees, J. M. (2014) Soybean Yield, Evapotranspiration, Water Productivity, And Soil Water Extraction Response To Subsurface Drip Irrigation and Fertigation. - Transactions of the Asabe 57(3): 729-748.

[19] Kanaan, B. A .J., Saud, H. M., Othman, R. (2013): Influence of molybdenum in association with rhizobium on enhanced biological nitrogen fixation, growth and yield of soybean under drip irrigation system. - Legume Research 36(6): 522-527.

[20] Kang, M. S., Kim, S. M., Park, S. W., Lee, J. J. (2007): Assessment of reclaimed wastewater irrigation impacts on water quality, soil, and rice cultivation in paddy fields. Journal of Environmental Science and Health A 42:439-445.

[21] Karunakaran, V., Behera, U. K. (2015): Influence of sequential tillage and residue management practices on soil and root parameters in soybean (Glycine max) - wheat (Triticum aestivum) cropping system. - Indian Journal of Agricultural Sciences 85(2):182-188.

[22] Kasirajan, S., Ngouajio, M. (2012): Polyethylene and biodegradable mulches for agricultural applications: a review. - Agron. Sustain. Dev 32(2):501-529.

[23] Kirkova, Y. (2010): Irrigation regime effect on soil and plants. - Journal of Environmental Protection and Ecology 11(2): 577-585.

[24] Kirnak, H., Dogan, E., Turkoglu, H. (2010): Effect of drip irrigation intensity on soybean seed yield and quality in the semi-arid Harran plain, Turkey. - Spanish Journal of Agricultural Research 8(4):1208-1218.

[25] Kwan, R. A., Kalashnikov, A. A., Paramonov, A. I., Kaldarov, S. M. (2011): Water resources and prospects of their use in irrigation of the Republic of Kazakhstan. - Water economy of Kazakhstan 3

[26] Lakin, G. F. (1990): Biometry. 1st Edit., Moscow, pp: 352.

[27] Li, X., Simunek, J., Shi, H., Yana, J., Penga, Z., Gong, X. (2016b): Spatial distribution of soil water, soil temperature, and plant roots in a drip-irrigated intercropping field with plastic mulch. - European Journal of Agronomy 83: 47-56 
[28] Li, X., Zhang, X., Niu, J. (2016a): Irrigation water productivity is more influenced by agronomic practice factors than by climatic factors in Hexi Corridor, Northwest China. Sci. Rep. 6, 37971; doi:10.1038/srep37971

[29] Li, Zh., Tian, Ch., Zhang, R., Mohamed, I. (2015): Plastic mulching with drip irrigation increases soil carbon stocks of natrargid soils in arid areas of northwestern China. Current science 133: 179-185.

[30] Liu, M., Yang, J., Li, X., Yu, M., Wang, J. (2012): Effects of Irrigation Water Quality and Drip Tape Arrangement on Soil Salinity, Soil Moisture Distribution, and Cotton Yield (Gossypium hirsutum L.) Under Mulched Drip Irrigation in Xinjiang, China. Journal of Integrative Agriculture 11(3): 502-511.

[31] Mukherjee, A., Kundu, M., Sarkar, S. (2010): Role of irrigation and mulch on yield, evapotranspiration rate and water use pattern of tomato (Lycopersicon esculentum L.). Agricultural Water Management 1: 182-189.

[32] Paramonov, A. I. (2009): The present and future of irrigated agriculture of the Republic of Kazakhstan / http://www.rusnauka.com/23_D_/Agricole/50006.doc.htm

[33] Patent. 2015: Method for performing drip irrigation under plastic film for rice cropping applications, involves performing seed preparation, soil preparation, seeding, seedling management, irrigation management, fertilizer management and pest control. № 2015095989-a1.38136

[34] Profile of rice production in Southern Brazil: a comparison between irrigated and subsurface drip irrigated cropping systems. - Journal of Cleaner Production (2016), doi: 10.1016/j.jclepro.2016.09.207.

[35] Raina, J. N., Thakur, B. C., Bhandaria, R. (1998): Effect of drip irrigation and plastic mulch on yield, water use efficiency and benefit-cost ratio of pea cultivation. - Indian J. Soil Sci.

[36] Reddy, K. S., Kumar, M., Maruthi, V. (2015): Dynamics of well irrigation systems and $\mathrm{CO}_{2}$ emissions in different agroecosystems of south central India 108(11): 2063-2070

[37] Seyfi, K., Rashidi, M. (2007): Effect of drip irrigation and plastic mulch on crop yield and yield components of Cantaloupe. - Int. J. Agric. Biol. 9(2).

[38] Sharda, R., Mahajan, G., Siag, M. (2016): Performance of drip-irrigated dry-seeded rice (Oryza sativa L.) in South Asia. - Paddy and Water Environment 15(1): 93-100.

[39] Terletskaya, N., Kurmanbayeva, M. (2017): Change in leaf anatomical parameters of seedlings of different wheat species under conditions of drought and salt stress.- Pakistan Journal of Botany.3:857-865.

[40] Tian, F., et al. (2016): Energy balance and canopy conductance for a cotton field under film mulched drip irrigation in an arid region of northwestern China. Agric. Water Manage. http://dx.doi.org/10.1016/j.agwat.2016.06.029

[41] Tiwari, K. N., Ajai Singh, M. P. K. (2003): Effect of drip irrigation on yield of cabbage (Brassica oleracea L. var. capitata) under mulch and non-mulch conditions. - Journal of Agricultural Water Management 58 (1): 19-28.

[42] Tiwari, K. N., Mal, P. K., Singh, R. M., Chattopadhyay, A. (1998): Response of okra (Abelmoschus esculentus (L.) Moench.) to drip irrigation under mulch and non-mulch conditions. - Agricultural Water Management 38: 91-102.

[43] Vial, L. K., Lefroy, R. D. B., Fukai, S. (2015): Application of mulch under reduced water input to increase yield and water productivity of sweet corn in a lowland rice system. Field crops research 171:120-129.

[44] Wang, F.-X., Wu, X.-X, Shock, C., Chua, L.-Y. (2011): Effects of drip irrigation regimes on potato tuber yield and quality under plastic mulch in arid Northwestern China. - Field Crops Research 122: 78-84.

[45] Water resources of Kazakhstan in the New Millennium: 2004. A Review. - Almaty., 132. 
[46] Yaghia, T., Arslana, A., Naoumb, F. (2013): Cucumber (Cucumis sativus, L.) water use efficiency (WUE) under plastic mulch and drip irrigation. - Agricultural Water Management 128: 149-157

[47] Zhang, J., Zhang, Sh., Chen, L., Wei, Ch. (2016): Alleviation of seeding chlorosis by plant growth regulators in drip-irrigated rice. - Acta Agriculturae Scandinavica, Section B-Soil \& Plant Science, http://www.tandfonline. com/doi/full/10. 1080 /09064710.2016. 1240828

[48] Zhang, T. B., Kang, Y., Liu, Sh. H., Liu, Sh. P. (2014): Alkaline phosphatase activity and its relationship to soil properties in a saline-sodic soil reclaimed by cropping wolfberry (Lycium barbarum L.) with drip irrigation. - Paddy Water Environ 12: 309-317.

[49] Zhang, X., Zhang, S, Zh., Zhu, Q. (2015): Effect of $\mathrm{HCO}_{3}^{-}$on rice growth and iron uptake under flood irrigation and drip irrigation with plastic film mulch. - Journal of plant Nutrition and Soil Science 178 (6): 944-952.

[50] Zhang, Y. L., Wanga, F. X., Shockb, C. C., Yanga, K. J. (2017): Influence of different plastic film mulches and wetted soil percentages on potato grown under drip irrigation. Agricultural Water Management 180: 160-171.

[51] Zhou, L., Feng, H., Zhao, Y., Qi, Zh., Zhang, T., He, J., Dyck, M. (2017): Drip irrigation lateral spacing and mulching affects the wetting pattern, shoot-root regulation, and yield of maize in a sand-layered soil. - Agricultural Water Management 184: 114-123.

[52] Zhu, Q. C., Wei, C. Z., Li, M. N, Zhu, J. L., Wang, J. (2013): Nutrient availability in the rhizosphere of rice grown with plastic film mulch and drip irrigation. - Journal of Soil Science and Plant Nutrition 13(4): 943-953.

[53] Zwart, S. J., Bastiaanssen, W. G. M. (2004): Review of measured crop water productivity values for irrigated wheat, rice, cotton and maize. - Agricultural Water Management 69: $115-133$. 